\title{
VERTICAL AND HORIZONTAL SUPPORT PRESSURE ALONG THE KULEKHANI III HEP TUNNEL ALIGNMENT, NEPAL
}

\section{Suman Panthee}

Journal of Institute of Science and Technology

Volume 21, Issue 1, August 2016

ISSN: 2469-9062 (print), 2467-9240(e)

Editors:

Prof. Dr. Kumar Sapkota

Prof. Dr. Armila Rajbhandari

Assoc. Prof. Dr. Gopi Chandra Kaphle

JIST, 21 (1), 112-118 (2016)



Published by:

Institute of Science and Technology

Tribhuvan University

Kirtipur, Kathmandu, Nepal 


\title{
VERTICAL AND HORIZONTAL SUPPORT PRESSURE ALONG THE KULEKHANI III HEP TUNNEL ALIGNMENT, NEPAL
}

\author{
Suman Panthee \\ Central Department of Geology, Tribhuvan University, Kirtipur, Nepal \\ Corresponding email: panthisuman@gmail.com
}

\begin{abstract}
Support pressure obtained in tunnel is considered as stresses for applied support. Therefore, estimation of support pressure in tunnel is important task for tunnel support design. Several equations are proposed to estimate support pressures. In this study, Barton equation was used for estimation support pressures along the tunnel of Kulekhani III HEP. The calculated support pressures were highly dependent on Q value and joint characteristics. Vertical and horizontal support pressures in the Marble and Quartzite followed the pattern as followed by Q but for other rocks support pressures were not only dependent on Q but had high influence of the joint characteristics. Support pressures obtained from the equation can also be used to estimate support pressure to some extent but modification is necessary. The equations can be considered for obtaining maximum support pressures for support design.
\end{abstract}

Key words: Support pressure, Q-system, Stress, Support

\section{INTRODUCTION}

Underground excavation is mostly carried out in grounds that have equilibrium or partially equilibrium state of stresses in rock mass. Ground having complex geological condition comprises jointed rock mass poses in-situ stress fields. As underground opening is excavated in such ground, nature of state of equilibrium of stresses presented before is disturbed and the stresses are redistributed. The re-distribution of stresses may result in large differential stresses at the boundary of the underground openings. If the rock mass is weak and differential stresses are high, the mass may be subjected to fail and equilibrium may be achieved through failure if the opening is unsupported condition. Therefore, in-situ stresses of ground have always been assessed to avoid or decrease troublesome stress induced failures (Cook 1965, Exadaktylos \& Tsoutrelis 1995, Rajmeny et al. 2002, Diederichs et al. 2004, Phillipson 2008). Prediction of failure potential is, therefore of great importance to a designer for designing a stable and ductile support system of the tunnel. Therefore, understanding of state of stresses around tunnel after excavation is important to design stable tunnel or underground excavations.

Hydraulic fracturing (Bjarnason 1986), HTPF (Haimson \& Cornet 2003) and overcoring method (Kim \& Franklin 1987, Sjoberga et al. 2003) methods are commonly used methods in present day for in-situ stress measurements in underground. Hudson and Cornet (2003) emphasized that establishment of precise values of stresses are not always easy for the components of the in-situ rock stress state using these methods. Some alternative methods had been proposed if in-situ measured data of rock stress were either lacking or not sufficiently reliable due to practical difficulties. Method of applied loads used by Wilson and Gore (1908), photo-elastic gels method by Farquharson and Hennes (1940) for the study of stress concentrations in tunnels and inversion method for the experimental determination of dead-load stresses in two-dimensional problems introduced by Rocha \& Serafim (1955) and Rocha (1965) are commonly used traditional methods. Borehole breakouts method in early days was reported by Leeman (1964). The relationship between historical rock stress and Kaiser Effect is summarized by $\mathrm{Li}$ and Nordlund (1993). Martin et al. (1990) suggested seismic and micro-seismic method and Hakala (1999) suggested core discing method. Similarly, Vallejo and Hijazo (2008) described procedure for assessing the ratio between in-situ current stresses and far-field tectonic stresses in the rock mass.

These new proposed methods are commonly used in required area or in design stage. In common working area and low stressed regime where stresses are not major issue, tunnel closure is 
estimated by estimating support pressure method. The support pressure is modified concept of traditionally used stress estimation methods'method of applied loads' and 'dead-load stresses'. Initially, Terzaghi (1946) proposed a classification method that suggested support pressure estimation equations. Unal (1983), proposed another equation based on RMR rock mass classification for estimate support pressure. Goel and Jethwa (1991) have modified the Unal's equation and proposed another equation for vertical support pressure estimation. Barton et al. (1975) studied 200 tunnel opening and proposed empirical correlation for ultimate support pressure based on rock mass quality (Q). Singh et al. (1992) and Grimstad and Barton (1993) modified the equation of support pressure proposed by Barton et al. (1975). Later, Bhasin and Grimstad (1996) suggested a vertical support pressure equation for poor rock mass.
Present study was carried out along the tunnel alignment of the Kulekhani III Hydroelectric Project which lies in low stress regime. Since the study area is in low-stressed ground and passes through different rock types, support pressures along the tunnel were estimated based on $\mathrm{Q}$.

\section{MATERIALS AND METHODS}

\section{Study area}

The study area is located in Makwanpur district, central Nepal, about $120 \mathrm{~km}$ south from the capital city Kathmandu and is easily accessible through Tribhuvan Highway or the Balkhu-Bhainse road. The project site lies aside of the highway with its headrace tunnel more or less parallel to the highway. The Kulekhani III Hydroelectric Project extends from approximately $27^{\circ} 28^{\prime} 18^{\prime \prime} \mathrm{N}$ to $27^{\circ} 30^{\prime} 45^{\prime \prime} \mathrm{N}$ latitude and $85^{\circ} 2$ ' $10^{\prime \prime} \mathrm{E}$ to $85^{\circ} 2^{\prime} 53^{\prime \prime} \mathrm{E}$ longitude. The location map of the study area is shown in Fig. 1.

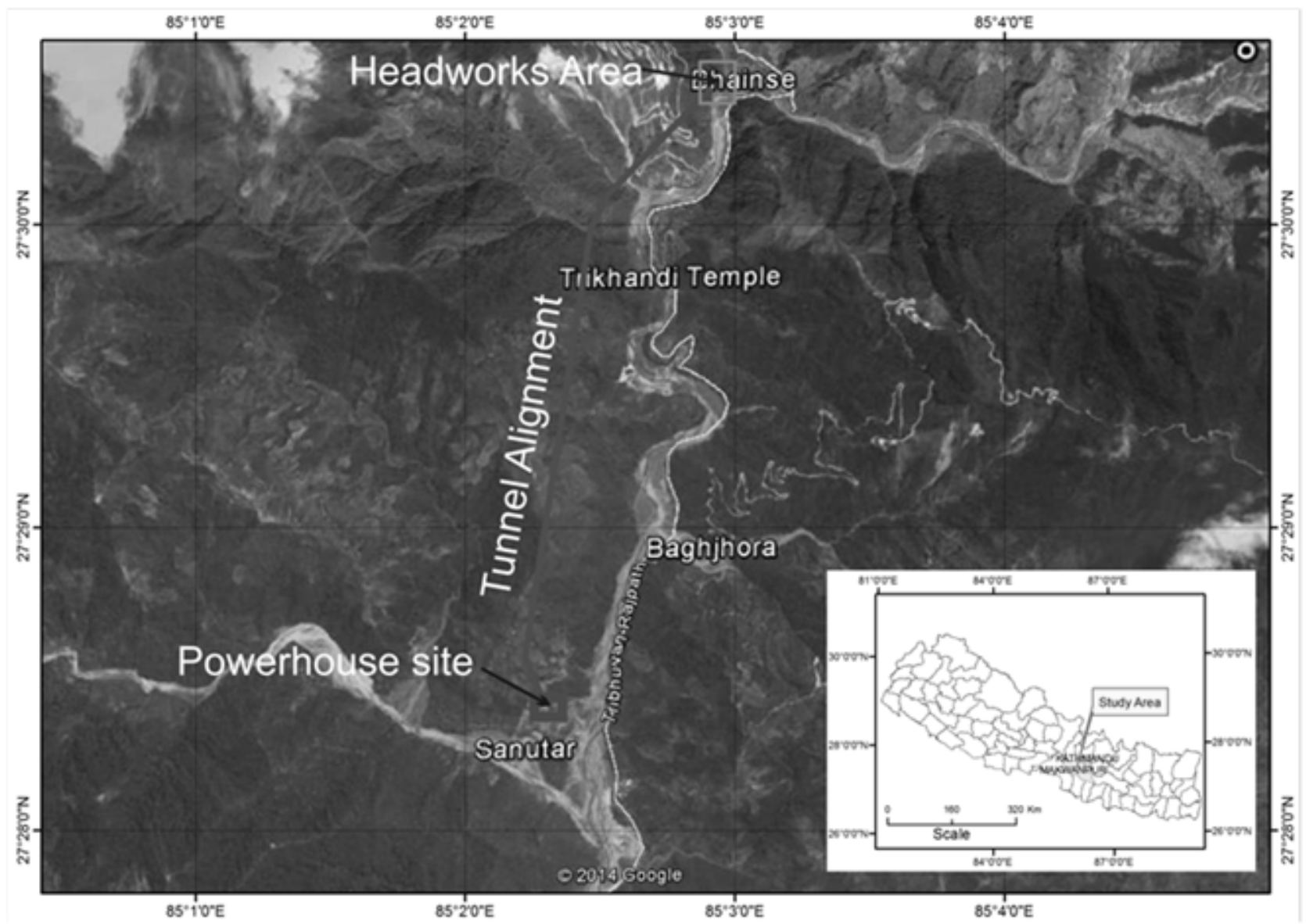

Fig. 1. Location map and tunnel alignment of the study area.

\section{Geology along tunnel alignment}

The study site lies in the southernmost part of the Mahabharat Synclinorium, which comprises of
Kathmandu Complex and Nawakot Complex. Geologically the tunnel alignment lies in five stratigraphic formations proposed by Stöcklin and 
Bhattarai (1977). The stratigraphic units are Bhainsedovan Marble, Raduwa Formation, Robang Formation, Malekhu Limestone and Benighat Slates (Table 1). The five stratigraphic formations comprises eight lithological units-marble, garnetiferrous schist, quartziticschist, schistose quartzite, quartzite, phyllite, silicious dolomite and slate, ranged from soft slate to massive and hard quartzite. The topography and rock type along the tunnel alignment is given in Fig. 2. The thickness of the rock type differs.

Table 1. Stratigraphy of the Lesser Himalaya Central Nepal (Modified after Stöcklin and Bhattarai, 1977)

\begin{tabular}{|c|c|c|c|c|}
\hline Complex & Group & Unit & Lithology & Thickness (m) \\
\hline \multirow{6}{*}{ 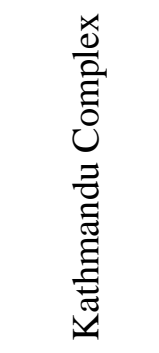 } & \multirow{6}{*}{$\begin{array}{l}\text { Bhimphedi } \\
\text { Group }\end{array}$} & Markhu Formation & Marble, Schist & 1000 \\
\hline & & KhulekhaniFormatioon & Quartzite, Schist & 2000 \\
\hline & & Chisapani Quartzite & Quartzite & 400 \\
\hline & & Kalitar Formation & Schist, Quartzite & 400 \\
\hline & & Bhainsedhovan Marble & Marble & 800 \\
\hline & & Raduwa Formation & Garnet Schist, Quartzite & 1000 \\
\hline & & \multicolumn{3}{|c|}{---------Mahabharat Thrust (MT) --------- } \\
\hline \multirow{3}{*}{ 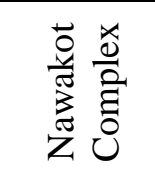 } & \multirow{3}{*}{$\begin{array}{l}\text { Upper } \\
\text { Nawakot } \\
\text { Group }\end{array}$} & Robang Formation & Phyllite, quartzite & $200-1000$ \\
\hline & & Malekhu Limestone & Limestone, dolomite & 800 \\
\hline & & Benighat Slate & Slate & $500-3000$ \\
\hline
\end{tabular}
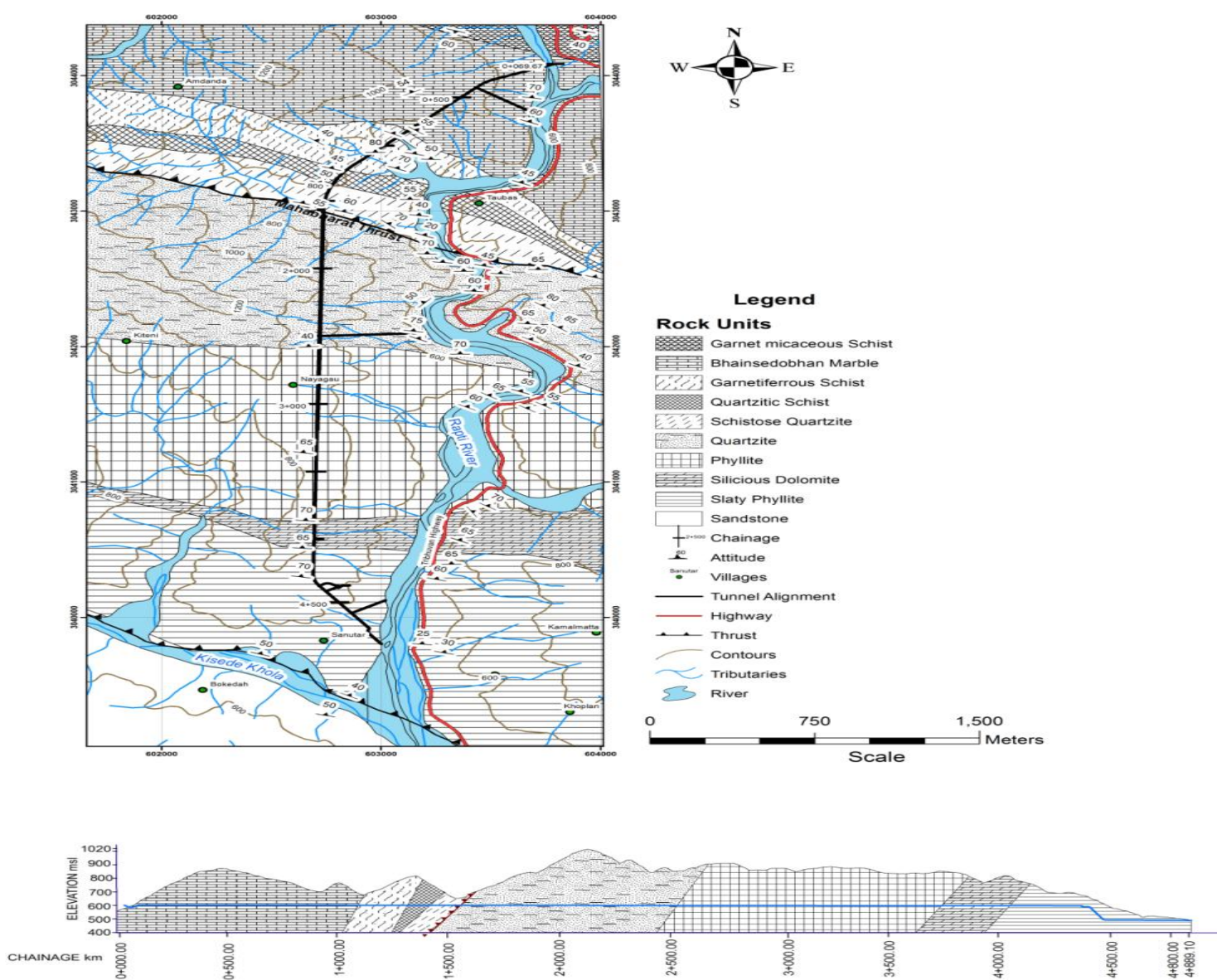

Fig. 2. Geological map and L-section of the tunnel alignment of the study area (modified after Panthee et al. 2016). 


\section{Methodology}

The empirical approach was basically based on the rock mass classification approach. For the propose geo-mechanical properties were used to determine the roof pressure and horizontal pressure in the excavated tunnel.

Barton et al. (1975) has proposed that vertical pressure and horizontal pressure in tunnel can be estimated using following equations. Equation 1 gives the vertical pressure and Equation 2 gives the horizontal pressure in tunnel.

$\mathrm{p}_{\mathrm{v}}=\left(\frac{0.2}{\mathrm{j}_{\mathrm{r}}}\right) \mathrm{Q}^{-\frac{1}{3}}$.

and

$\mathrm{p}_{\mathrm{h}}=\left(\frac{0.2}{\mathrm{j}_{\mathrm{r}}}\right) Q_{w}^{-\frac{1}{3}}$

where,

$\mathrm{p}_{\mathrm{v}}=$ ultimate roof support pressure in $\mathrm{MPa}$, $\mathrm{p}_{\mathrm{h}}=$ ultimate wall support pressure in MPa and
$\mathrm{Q}_{\mathrm{w}}=$ wall factor

Barton et al. (1975) further suggested that if the number of joint sets is less than three, then the Equations 1 and 2 is modified into following relations for the vertical and horizontal pressure calculation.

$\mathrm{p}_{\mathrm{v}}=\frac{0.2 \mathrm{~J}_{\mathrm{n}}^{1 / 2}}{3 . \mathrm{J}_{\mathrm{r}}} Q^{-\frac{1}{3}}$
$\mathrm{p}_{\mathrm{h}}=\frac{0.2 . \mathrm{J}_{\mathrm{n}}^{1 / 2}}{3 . \mathrm{J}_{\mathrm{r}}} Q_{w}^{\frac{1}{3}}$

\section{RESULTS AND DISCUSSION}

Rock mass classification based on Q was carried out along the tunnel in $2-5 \mathrm{~m}$ interval. The distribution of $\mathrm{Q}$ is presented in Fig. 2. The maximum and minimum $\mathrm{Q}$, arithmetic mean, standard deviation from the mean and coefficient of variation of $\mathrm{Q}$ values were calculated. The result of the calculation of Q is shown in Table 2.

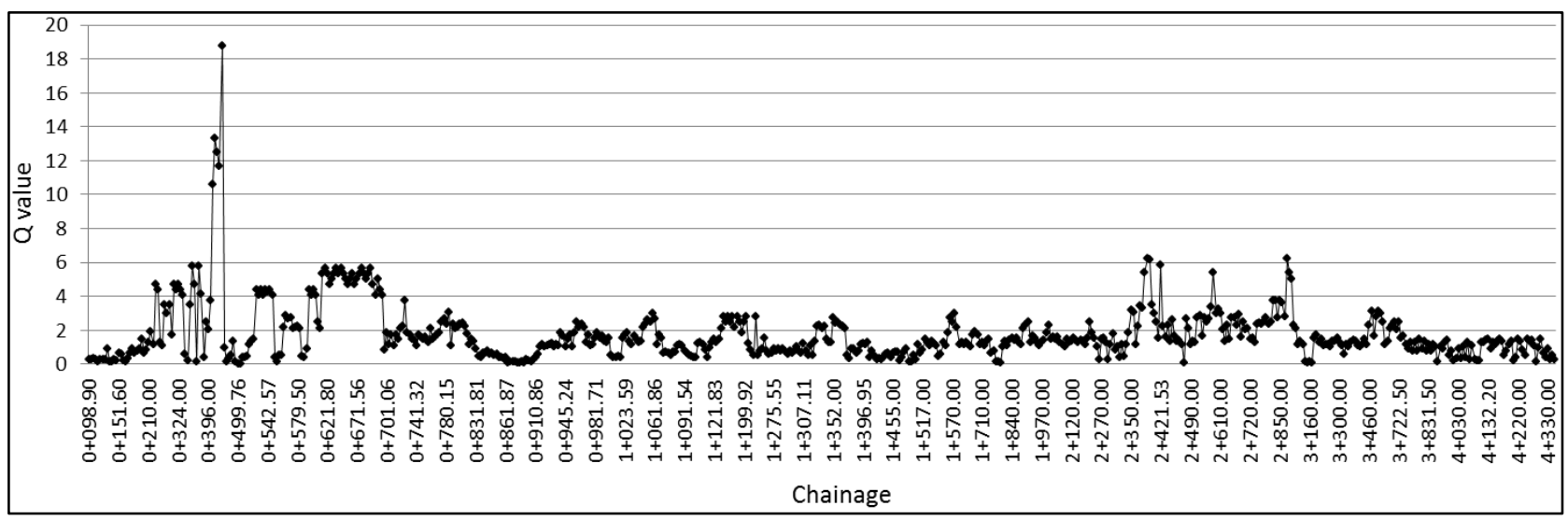

Fig. 3. Distribution of $Q$ along the tunnel.

The diversity of Q value is high in the Marble and low in the Quartzitic Schist. The Marble has highest and the Siliceous Dolomite has lowest average Q value.

Table 2. Geo-mechanical classification on the basis of $Q$

\begin{tabular}{|c|c|c|c|c|c|c|c|}
\hline \multirow{2}{*}{ Lithology } & \multicolumn{2}{|c|}{ Chainage } & \multirow{2}{*}{$Q \max$} & \multirow{2}{*}{$Q \min$} & \multirow{2}{*}{$\begin{array}{l}\text { Average } \\
\text { (AM) }\end{array}$} & \multirow{2}{*}{ SD } & \multirow{2}{*}{$\begin{array}{c}\text { Coefficient of } \\
\text { variation }(\mathrm{CV})\end{array}$} \\
\hline & From & To & & & & & \\
\hline Marble & $0+000$ & $0+795.00$ & 18.75 & 0.03 & 2.76 & 2.67 & $96.62 \%$ \\
\hline $\begin{array}{l}\text { Garnetiferr } \\
\text {-ous Schist }\end{array}$ & $0+795$ & $1+029.73$ & 2.50 & 0.05 & 1.05 & 0.69 & $65.49 \%$ \\
\hline $\begin{array}{l}\text { Quartzitic } \\
\text { Schist }\end{array}$ & $1+029.73$ & $1+339.00$ & 3.00 & 0.37 & 1.35 & 0.78 & $57.68 \%$ \\
\hline $\begin{array}{l}\text { Schistose } \\
\text { Quartzite }\end{array}$ & $1+339.00$ & $1+420.00$ & 2.71 & 0.27 & 1.26 & 0.74 & $58.85 \%$ \\
\hline
\end{tabular}




\begin{tabular}{|l|l|l|l|l|l|l|l|}
\hline Quartzite & $1+420.00$ & $2+476.00$ & 6.25 & 0.10 & 1.48 & 1.06 & $71.69 \%$ \\
\hline Phyllite & $2+476.00$ & $3+826.00$ & 6.25 & 0.07 & 1.97 & 1.11 & $56.07 \%$ \\
\hline $\begin{array}{l}\text { Siliceous } \\
\text { Dolomite }\end{array}$ & $3+826.00$ & $4+073.00$ & 1.41 & 0.17 & 0.79 & 0.39 & $49.48 \%$ \\
\hline Slate & $4+073.00$ & $4+400.00$ & 1.50 & 0.17 & 0.92 & 0.47 & $50.91 \%$ \\
\hline
\end{tabular}

On the basis of Q, vertical and horizontal support pressures were determined along the tunnel. Equations 1 to 4 were used to determine the vertical and horizontal support pressure. Determined values along the tunnel in 3 to $5 \mathrm{~m}$ intervals were plotted in graphs given in Fig. 4 and 5.

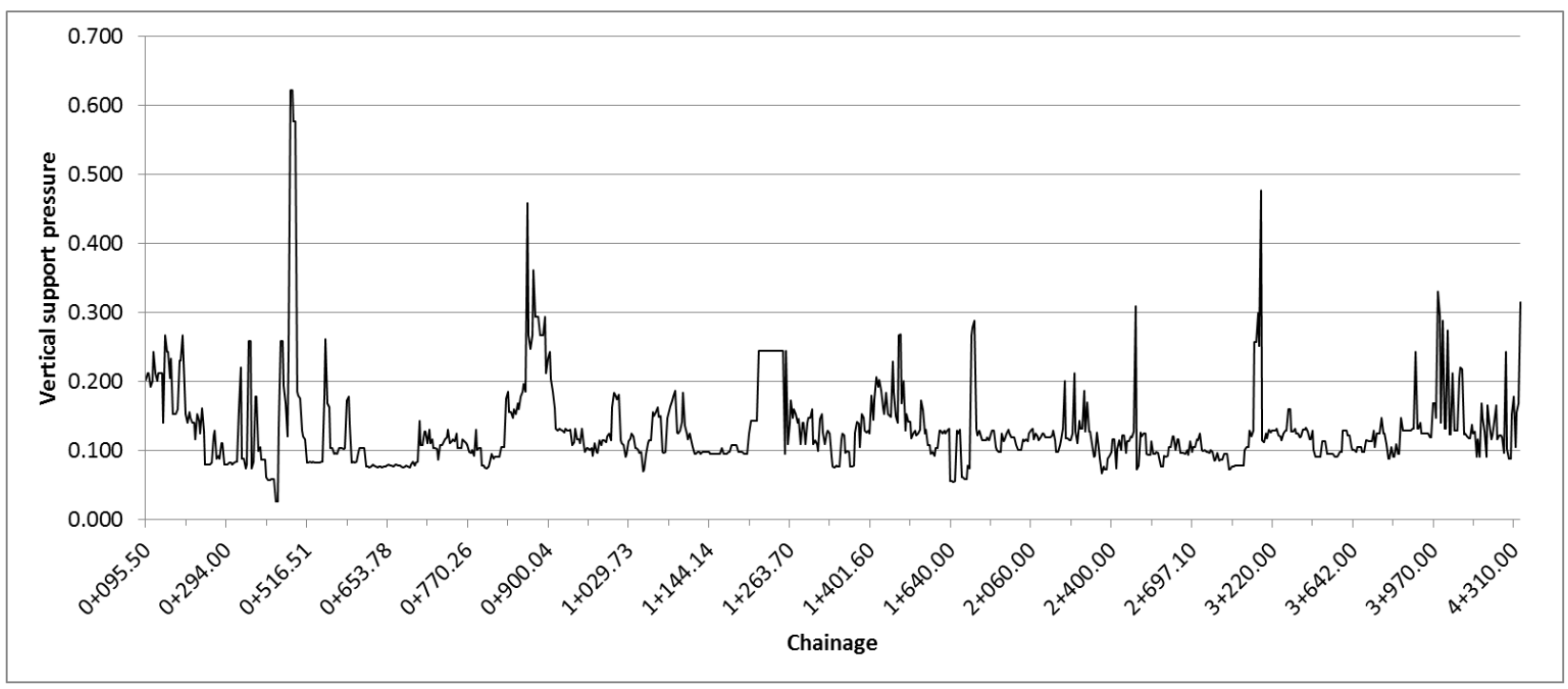

Fig. 4. Distribution of vertical support pressure along the tunnel.



Fig. 5. Distribution of horizontal support pressure along the tunnel.

The distributions of support pressures (horizontal and vertical) are highly inconsistent because of the variation of $\mathrm{Q}$. The calculated support pressures using Barton et al. (1975) were highly dependent according $\mathrm{Q}$ and joint characteristics. Both vertical and horizontal support pressures are in similar trend 
but the values are different. In the case of the Marble and Quartzite, vertical and horizontal support pressures follow the pattern as followed by $\mathrm{Q}$ shown in Fig. 3. For other rocks, it not only dependent on $\mathrm{Q}$ but has high influence on the joint characteristics.

Sheorey (1991) studied 44 case studies in coal mines in India and found that Q-system overestimated the support pressure. Therefore he modified the equation proposed by Barton et al. (1975) and added new parameter, i.e. tunnel dimension. Similarly, the support pressure in tunnels increased directly with the tunnel width (Terzaghi 1946). The support pressures in this study were independent of tunnel dimension and directly dependent with $\mathrm{Q}$ and joint characteristics. Therefore the present support pressure can be considered as maximum support pressures for support design.

Singh et al. (1992) suggested that is likely to occur in a tunnel section where the height of overburden in meters exceeds $350 \mathrm{Q}^{1 / 3}$ and the short-term wall support pressure may be obtained from new correlations proposed by substituting $\mathrm{Q}_{\text {wall }}$ for $\mathrm{Q}$. Squeezing case is not observed and the condition $350 \mathrm{Q}^{1 / 3}$ also meet in the present study. Therefore, $\mathrm{Q}$ system can be used to estimate support pressure in some extent but modification is necessary.

\section{CONCLUSION}

Support pressure estimation in tunnel is important task for tunnel support design. For the support pressure estimation, several equations are proposed. The calculated support pressures using Barton et al. (1975) are highly dependent according Q and joint characteristics. Vertical and horizontal support pressures in the Marble and Quartzite follow the pattern as followed by Q but for other rocks, it is not only dependent on $\mathrm{Q}$ but has high influence the joint characteristics. Support pressures obtained from equation proposed by Barton et al. (1975) can be used to estimate support pressure to some extent but modification is necessary and the equations can be considered as maximum support pressures for support design.

\section{REFERENCES}

Barton, N., Lien, R. and Lunde, J. 1975. Estimation of support requirements for underground excavations. $\mathrm{XVI}^{\text {th }}$ Symposium on Rock Mechanics, University of Minnesota, Minneapolis, USA, pp. 163-177.
Bjarnason, B. 1986. Hydro fracturing rock stress measurements in the Baltic Shield. Licentiatethesis, Lulea University, Sweden, pp122.

Cook, N. G. W. 1965. The failure of rock. International Journal of Rock Mechanics and Mining Science and Geomechanics, pp 389403.

Diederichs, M. S., Kaiser, P. K. and Eberhardt, E. 2004. Damage initiation and propagation in hard rock during tunnelling and the influence of near-face stress rotation. International Journal of Rock Mechanics and Mining Sciences 41:785-812.

Exadaktylos, G. E. and Tsoutrelis, C. E. 1995. Pillar failure by axial splitting in brittle rocks. International Journal of Rock Mechanics and Mining Science and Geomechanics 32:551-562.

Farquharson, F. B. and Hennes, R. G. 1940. Gelatin models for photoelastic analysis of stress in earth masses. Civil Engineering 10(4): 211214.

Goel, R. K. and Jethwa, J. L. 1991. Prediction of support pressure using RMR classification. Proceeding of Indian Getech Conference, Surat, India, pp 203-205.

Grimstad, E and Barton, N. 1993. Updating of the Q-system for NMT. Int. Symposium on Sprayed Concrete - Modern use of wet mix sprayed concrete for underground support, Fagernes. Eds: Kompen, Opsahll and Berg, Norwegian Concrete Association, Oslo, pp 44-66.

Haimson, B. C. and Cornet, F. H. 2003. ISRM suggested methods for rock stress estimation-Part 3 hydraulic fracturing (HF) and or hydraulic testing of pre-existing fractures HTPF. International Journal of Rock Mechanics and Mining Sciences 40:1011-1020.

Hakala, M. 1999. Numerical study on core damage and interpretation of in situ state of stress. Posiva Report, pp 234.

Hudson, J. A. and Cornet, F. H. 2003. Special issue on rock stress estimation. International Journal of Rock Mechanics and Mining Sciences 40:955.

Kim, K and Franklin, J. A.1987. Suggested methods for rock stress determination. International Journal of Rock Mechanics and 
Mining Science and Geomechanics 24:5373.

Leeman, E. R. 1964. The measurement of stress in rock-Part 1, "The principles of rockstressmeasurement". Journal of the South African Institute of Mining and Metallurgy 65:45-81.

Li, C and Nordlund, E. 1993. Experimental verification of the Kaiser effect in rocks. Rock Mechanics and Rock Engineering 26:333-351.

Martin, C. D., Read, R. S. and Lang, P. A. 1990. Seven years of in situ stress measurements at the URL, an overview. In: Hustrulid, W., Johnson, G. (Eds.), Proceedings of the $31^{\text {st }}$ US Symposium on Rock Mechanics. A.A. Balkema, pp.15-26.

Panthee S, Singh P. K., Kainthola A and Singh T. N. 2016.Control of rock joint parameters on deformation of tunnel opening. Journal of Rock Mechanics and Geotechnical Engineering, Doi: 10.1016/j.jrmge.2016.03.003.

Phillipson, S. E. 2008. Texture, mineralogy, and rock strength in horizontal stress related coal mine roof falls. International Journal of Coal Geology 75:175-184.

Rajmeny, P.K., Singh, U.K. and Sinha, B.K.P. 2002. Predicting rock failure around bore holes and drives adjacent to stopes in Indian mines in high stress regions. International Journal of Rock Mechanics and Mining Sciences 39:151-164.

Rocha, M. 1965. Structural model techniques, some recent developments. Zienkiewicz, O. C., and G. S. Holister (Eds.), Stress analysis, London, Wiley, pp. 385-424.

Rocha, M. and Serafim, J.L. 1955. Analysis of concrete dams by model tests. $5^{\text {th }}$ Congress on Large Dams, Paris, Commun. No. C 36.
Sheorey, P. R. 1991. Experiences with application of the NGI classification to coal measures. International Journal of Rock Mechanics and Mining Sciences and Geomechanics 28 (1):27-33.

Singh, B., Jethwa, J. L., Dube, A. K. and Singh, B. 1992. Correlation between observed support pressure and rock mass quality. International Journal of Tunnelling and Underground Space Technology,Pergamon 7(1):59-74.

Sjoberga, J., Christiansson, R. and Hudson, J. A. 2003. ISRM Suggested Methods for rock stress estimation-Part—over coring methods. International Journal of Rock Mechanics and Mining Sciences 40:9991010.

Stőcklin J and Bhattarai K. D. 1977. Geology of Kathmandu Area and Central Mahabharat Range, Nepal Himalaya. Kathmandu. Report of Department of Mines and Geology, UNDP, pp 86.

Terzaghi, K. 1946. Rock defects and loads on tunnel support. Introduction to Rock Tunnelling with Steel Supports. Eds: R. V. Proctor and T. L. White, Commercial Sheering and Stamping Co., Youngstown, Ohio, U.S.A., pp271.

Unal, E. (1983). Design guidelines and roof control standards for coal mine roofs. $\mathrm{PhD}$ thesis, Pennsylvania State University, University Park, pp 355.

Vallejo, L. I. G. and Hijazo, T. 2008. A new method of estimating the ratio between in situ rock stresses and tectonics based on empirical and probabilistic analyses. Engineering Geology 101:185-194.

Wilson, J. S. and Gore, W. 1908. Stresses in dams: An experimental investigation by means of India rubber models. Proceedings of the Institution of Civil Engineering. 172, Part 2, Paper No. 3705. 